\title{
ANALYSIS OF MANAGERIAL COMPONENTS IN MOSQUITO VECTORS (AEDES AEGYPTI) CONTROL IN THE BUFFER AREA OF THE CLASS 1 SURABAYA PORT HEALTH OFFICE
}

\author{
Fauzia Yulianti Ramadhani \\ Departement of Enviromental Health, \\ Faculty of Pubilc Health, Airlangga University, Surabaya, Indonesia \\ Correspondence address: Fauzia Yulianti \\ Email: fauzia.yulianti.ramadhani-2015@fkm.unair.ac.id
}

\begin{abstract}
The Aedes aegypti index in the buffer area of the Class 1 Surabaya Port Health Office was in accordance with the Standard Operating Procedures (SOP) as stated in the Regulation of the Indonesian Ministry of Health Number 431 of 2007 (431/MENKES/SK/IV/2007) on Technical Guidelines for Control of Environmental Health Risks in Ports/Airports/Cross-Border in the Context of Health Quarantine. The Port Health Office has responsibilities to control environmental risks, one of which was the Aedes aegypti mosquitos in the borders. This study was descriptive observational and aimed to analyze the managerial components in Aedes aegypti mosquito control in the buffer area ofthe Class 1 Surabaya Port Health Office in Surabaya. The research variables (factors that determine control activities) were manpower, money, methods, materials, markets, machines, and information. The research subjects were two officers at Class 1 Surabaya Port Health Office and five cadres who monitored larva. Data were analyzed descriptively. The results explained that manpower, money, materials, market, technology, and information were all in accordance with the SOP of the Surabaya Port Health Office. However, the larva survey method did not comply with the SOP as officers still used the visual method. It was concluded that managerial components in Aedes aegypti control by Class 1 Surabaya Port Health Office followed the SOP except in their larva survey method. The researchers recommended carrying out a larva survey method by taking 1 larva from each container (single larva) at a time.
\end{abstract}

Keywords: Aedes aegypti, control vector, managerial components.

\section{INTRODUCTION}

The revised International Health Regulations (IHR) of 2005 only mandates handling infected people and advising to call the nearest health service unit if symptoms of illness appear, but not mentioning the requirement of quarantine. Failure to take the actions may not overcome the global threat of disease caused by environmental change, resulting in a public health emergency of international concern (Indonesian Ministry of Health, 2007).

Preventive actions from the exit and entry of diseases, especially quarantine diseases, are the main strategic function of the Port Health Office (Surabaya Port Health Office). According to the Regulation of the Indonesian Ministry of Health Number 2348 of 2011
(2348/MENKES/PER/XI/2011)

on Organization and Work Procedures of the Port Health Office, the Surabaya Port Health Office is a unit that technically works under the Ministry of Health and reports their work to the Directorate General of Disease Control and Health Environment.

The Surabaya Port Health Office has authority over land borders and monitors the entry and exit routes of carriers from one country to another in ports, airports, and land borders. These areas have the potential to become hubs for disease carriers moving from one country or region to another. Therefore, ports and airports are places worth investment since they are prone to vector-transmitted disease disturbances.

The work areas of the Class 1 Surabaya Port Health Office are Tanjung 
Perak Surabaya, Gresik, Tuban, Kalianget, and Juanda Airport. Health problems that occur in the Juanda Airport environment are sorted out by the Class 1 Surabaya Port Health Office. This was an effort to control environmental risks by preventing the spread of infectious diseases and others, especially in the perimeter and buffer area according to standards in a professional manner. The numerous activities in the Juanda Airport area, where people and planes from various regions pass, have caused the airport to become a potential breeding ground area for disease vectors. One of them is the Aedes aegypti mosquito vector which can cause Dengue Hemorrhagic Fever (DHF). According to Atikasari and Sulistyorini (2018), the distribution of the Aedes aegypti vector could be extensively widespread in both densely populated cities and rural areas.

In subtropical and tropical areas such as the Northern islands of Australia and the Indonesian archipelago, mosquitoes, especially the Aedes aegypti, are found easily. Mosquitoes can carry 4 different dengue viruses, one of which is the cause of DHF (Indonesian Ministry of Health, 2016). DHF is an endemic disease that occurs year-round in many tropical and subtropical areas. This is even more prominent during the rainy season when conditions are favourable for mosquitoes to breed. In general, this is the time where large numbers of people will be infected for a short time which may cause outbreak.

Humans have been susseptable to the four dengue viruses, in Africa and Southeast Asia, since 100-800 years ago. The dengue virus rapidly spread during World War 2 where mosquitoes were tranfered through the goods shipping, potentially contributing to the global spread of DHF (Centers for Disease Control and Prevention, 2010).

Nine countries were infected with dengue fever before 1970. However, DHF is still a disease endemic in over 100 countries today. The highest number of dengue cases, currently, was found in the
West Pacific, East Mediterranean, America, Africa, Southeast Asia, America. The number of cases in Southeast Asia, the Western Pacific, and the United States exceeded 1.2 million cases in 2008 and 2.3 million cases in 2010. In 2013 there were reports of 2.35 million cases in America with 37,687 cases of severe dengue. Not only was the current number of dengue cases increasing, but also it spread outside the tropic and subtropic areas such as Europe. In 2010, local transmission was first reported in Croatia and France. In 2010, there were over 2,000 cases of DHF in more than 10 countries in Europe. In 2012, around 500,000 people infected with DHF required hospitalization each year with most children died or $2.5 \%$ of the total deaths (World Health Organization, 2014).

Based on the annual report of Class 1 Surabaya Port Health Office, the House Index (HI), Container Index (CI), and Breteau Index (BI) in the buffer survey area were still above the Standard Operating Procedures (SOP) as stated in the Decree of the Indonesian Minister of Health Number 431 of 2007 (431/MENKES/SK/IV/2007) concerning Technical Guidelines for Environmental Health Risk Control at Ports/Airports/Cross-Border in the Context of Health Quarantine.

DHF becomes a significant public health issue in Indonesia. According to Istiqomah and Syahrul (2016), activity, mobility, and the habit of hanging clothes are risk factors of DHF in children aged less than 15 years. In line with the increase in community density and mobility, the distribution area of DHF and the numbers of the infected people may increase as well. In 1968, 58 people in Surabaya were infected with dengue fever, resulting in 24 deaths and a $41.3 \%$ mortality rate. Since then, DHF has spread widely throughout Indonesia (Indonesian Ministry of Health, 2010).

The Aedes aegypti mosquitoes
vector control measures include 
monitoring, identification, and the eradication of adult mosquitoes and larva (Nani, 2017). The Aedes aegypti mosquitoes control in the Class 1 Surabaya Port Health Office is carried out by the Environmental Risk Control Division in the Vector Control and ContagiousDisease Animals section. This section has the task of developing partnership networks, work and technology, as well as training and education in regards to controlling infection-transmitting animals and vectors in an airport environment; studying and disseminating information; controling pesticides; eradicating diseasetransmitting insects, fleas, and rats; coordinating the implementation of the eradication of infectious insects; preparing reports, evaluatting, monitoring, and preparing materials.

From the cases described, the prevention and eradication program for DHF at the Class 1 Surabaya Port Health Office require managerial activities such as planning a program. According to Manullang (2008), the management components include $6 \mathrm{M}+1 \mathrm{I}$ (man, money, methods, materials, market, machine, and information) and need to be implemented in the program.

The standard control measures for the Aedes aegypti mosquito vector that has been done by the Class 1 Surabaya Port Health Office included (1) personnel (man), (2) budget (money), (3) methods, tools, and materials, (4) marketing activities (market), (5) technology (machine), and (6) information. These factors were interrelated and affected the results of control measures. Based on Mufidz's research (2016), the implementation of Aedes aegypti mosquito control activities at the Tegal District Health Office depended on personnel, infrastructure, and funding. To further study this, the current research aimed to analyse the managerial components carried out by the Class 1 Port Health Office of Surabaya in mosquito vector control (Aedes aegypti) in the buffer area.

\section{METHODS}

This study was observational research, where observations were conducted without intervening on the research subjects. The research population was the personnel responsible for the Aedes aegypti mosquito vector control at the Class 1 Surabaya Port Health Office of the Juanda Airport (2 people) and vectormonitoring personnel (5 people) in Semampir village, Sedati sub-district, Sidoarjo city. The sample used in this study was the total population. The study was conducted at the Class 1 Surabaya Port Health Office, specifically the Juanda Airport work area.

This study used both primary and secondary data. Secondary data were obtained from reports of budget (money) and information (information), while primary data were obtained from the interview and observation. Interviews were conducted to dive into the managerial components i.e., personnel (man), methods (method), tools and materials (materials), marketing or socialization (market), and technology (machines) which were compared to the SOP as stated in the Decree of the Indonesian Minister of Health Number 431 of 2007 (431/MENKES/SK/IV/2007) on Technical Guidelines for Environmental Health Risk Control at Ports/Airports/Cross-Border in the Context of Health Quarantine.

The standard vector control of Aedes aegypti mosquitoes included technical and implementing requirements. The technical requirement was that the mosquito vector control was conducted in the perimeter and airport buffer areas. Implementation of vector control should involve locations mapping, equipment needed for activities, control procedures, indexes calculations, and identification of adult mosquitoes and larva. Observations were made directly to the implementation of the vector control measures.

In this study, a data analysis was carried out descriptively by giving an 
overview of the results. This study obtained an ethical review passing statement from the Ethics Commission,
Faculty of Dental Medicine, Universitas Airlangga, No:

\section{RESULTS \\ Budget (Money)}

Table 1. Budget for Aedes aegypti Mosquito Control Program at Class 1 Surabaya Port Health Office

\begin{tabular}{|c|c|c|c|}
\hline Activities & Activity Components & $\begin{array}{l}\text { Frequency } \\
\text { per Year }\end{array}$ & Volume \\
\hline Larva survey & $\begin{array}{l}\text { Incentives for Larva- } \\
\text { monitoring personnel }\end{array}$ & 12 & 5 people \\
\hline $\begin{array}{l}\text { larvae } \\
\text { eradication }\end{array}$ & Larvicide powder & 12 & 10 grams/house in 1 urban village \\
\hline \multirow[t]{4}{*}{ Fogging } & $\begin{array}{l}\text { Refreshment of cadres } \\
\text { and supervisory } \\
\text { personnel }\end{array}$ & 4 & 2 cadres and 1 supervisor in 1 village \\
\hline & $\begin{array}{l}\text { Diesel purchase for } \\
\text { insecticide solutions }\end{array}$ & 4 & 19 liters per hectare \\
\hline & $\begin{array}{l}\text { Fuel purchase for a fog } \\
\text { machine }\end{array}$ & 4 & 3 liters per hectare \\
\hline & $\begin{array}{l}\text { Transportation fare for } \\
\text { supervisors }\end{array}$ & 4 & 1 person in 1 village \\
\hline Socialization & Leaflets or brochures & 12 & 50 people in 1 village \\
\hline
\end{tabular}

The budget allocated for Aedes aegypti mosquito control measures was in accordance with the SOP. The cost also included the larva-monitoring personnel, the procurement of larvicide powder, refreshment of cadres and health personnel, procurement of diesel fuel mixed with insecticides, procurement of fuel for fog machines, and transportation for supervisors. Meanwhile, the cost for outreach activities was issued for making leaflets or brochures.

The incentives were provided for 5 people per activity which was conducted 12 times a year. The 10 grams of larva pesticide was given per house in 1 urban village. Expenses spent for fogging activities were allocated for personnel's refreshments ( 2 cadres and 1 supervisor in 1 urban village), procurement of diesel (19 liters per hectare), procurement of fog engine fuel (3 liters per hectare), and transportation fare for supervisors (1 person in 1 village). While brochures or leaflets for socialization activities were disseminated to 50 people in 1 urban village.

\section{Method}

Table 2. Aedes aegypti Mosquito Control Method at Class 1 Surabaya Port Health Office

\begin{tabular}{ll}
\hline \multicolumn{1}{c}{ Control Measures } & Methods Used \\
\hline Larva survey & Visual \\
Identification of & Microscope \\
mosquito larva & identification \\
Larva eradication & $\begin{array}{l}\text { Small holes or } \\
\text { pores in the } \\
\text { larvicide } \\
\text { packaging }\end{array}$ \\
& $\begin{array}{l}\text { Fumigation } \\
\text { based on case } \\
\text { Fogging }\end{array}$ \\
& size and density \\
& figure \\
\hline
\end{tabular}


Tools

The equipment used during the program was mosquito larvae survey sheet, identification forms, and fogging machines.

Table 3. Aedes aegypti Mosquito Control Measures at Class 1 Surabaya Port Health Office

\begin{tabular}{lll}
\hline \multicolumn{1}{c}{$\begin{array}{c}\text { Control } \\
\text { Measures }\end{array}$} & \multicolumn{1}{c}{ Tools } \\
\hline Larva survey & 1. & Larva \\
& 2. & Form \\
& 2. & Stationery \\
& 3. & Larva survey kit \\
& 4. & Small bottles \\
Mosquito & 1. & Petri dish \\
Larva & 2. & Needle \\
Identification & 3. Preparatory slide \\
& 4. Slide cover \\
Larva & 5. Microscope \\
eradication & 1. Larvaeradication Form \\
Fogging & 2. Stationery \\
& 1. Fogging machine \\
& 2. Jerry can \\
\hline
\end{tabular}

\section{Materials}

Some materials were used for Larva eradication and fogging.

Table 4. Materials for Aedes aegypti Mosquito Control Measures at Class 1 Surabaya Port Health Office

\begin{tabular}{cll}
\hline Activities & Materials Used \\
\hline Larvaeradication & 1. & $\begin{array}{l}\text { Larvicide powder } \\
\text { (Temephos) }\end{array}$ \\
Fogging & 1. & Lamda Cyhalothrin \\
& 2. & Solar Dex \\
& 3. & Gasoline \\
\hline
\end{tabular}

\section{Socialization}

The socialization carried out by the Class 1 Surabaya Port Health Office was explained in Table 5.
Table 5. Socialization of Aedes aegypti Mosquito Control Measures at Class 1 Surabaya Port Health Office

\begin{tabular}{ll}
\hline \multicolumn{1}{c}{ Indicators } & \multicolumn{1}{c}{ Descriptions } \\
\hline Method & Extension \\
Target & Female in the work area of \\
& Class 1 Surabaya Port \\
& Health Office \\
Theory & 1. The life cycle of a \\
& mosquito \\
& 2. Bionomics of \\
& mosquitoes \\
& 3. The 4M plus effort \\
\hline
\end{tabular}

The socialization was carried out routinely through counseling on the vector life cycle (Aedes aegypti mosquito), the bionomic of Aedes aegypti mosquito, and the $4 \mathrm{M}$ plus effort (draining, closing water reservoirs, recycling, getting rid of used goods, eradicating larva, and avoiding mosquito bites). Besides, leaflets or brochures detailing the importance of the control measures and the dangers of dengue fever were also distributed.

\section{Technology}

Table 6. Use of Technology in Aedes aegypti Mosquito Control Measures at Class 1 Surabaya Port Health Office

\begin{tabular}{|c|c|}
\hline $\begin{array}{c}\text { Types of } \\
\text { Technology }\end{array}$ & Descriptions \\
\hline Hardware & $\begin{array}{l}\text { 1. Laptop or } \\
\text { computer } \\
\text { 2. Printer } \\
\text { 3. Microscope } \\
\text { 4. Fogging machine }\end{array}$ \\
\hline Software & $\begin{array}{l}\text { 1. Microsoft office } \\
\text { 2. Health Quarantine } \\
\text { Information } \\
\text { System Website } \\
\text { (SINKARKES) } \\
\text { 3. Email }\end{array}$ \\
\hline
\end{tabular}


Surabaya Port Health Office used technologies to report the results.

\section{Information}

The control measures for Aedes aegypti mosquitoes were reported monthly, annually, and lastly via the Health Quarantine Information System (SINKARKES). The information was reported to the Directorate General of Disease Prevention and Control of the Indonesian Ministry of Health. The profile of the Surabaya Port Health Office regarding the yearly accomplished activities was also submitted to the Indonesian Ministry of Health, the Directorate General of Disease Prevention and Control, the East Java Provincial Health Office, the Surabaya City Health Office, and other cross-institutions.

Table 7. Information about Aedes aegypti Mosquito Control Measures at Class 1 Surabaya Port Health Office

\begin{tabular}{|c|c|}
\hline \multirow{6}{*}{$\begin{array}{l}\quad \text { Variables } \\
\text { Types of } \\
\text { Report }\end{array}$} & Descriptions \\
\hline & 1. Monthly Report \\
\hline & 2. Annual Report \\
\hline & 3. SINKARKES Report \\
\hline & 4. Port Health Office \\
\hline & Profile \\
\hline \multirow{8}{*}{$\begin{array}{l}\text { Report } \\
\text { Dissemination }\end{array}$} & 1. Indonesian Ministry \\
\hline & of Health \\
\hline & 2. Directorate General \\
\hline & $\begin{array}{l}\text { of Disease Prevention } \\
\text { and Control }\end{array}$ \\
\hline & 3. East Java Provincial \\
\hline & Health Office \\
\hline & $\begin{array}{l}\text { 4. Surabaya City Health } \\
\text { Office }\end{array}$ \\
\hline & $\begin{array}{l}\text { 5. Other cross- } \\
\text { institutions }\end{array}$ \\
\hline
\end{tabular}

\section{DISCUSSION}

Personnel (Man)

Human Resources (HR) is a framework for formal systems within an organization to strengthen the efficiency and effectiveness of human potential and talents in achieving organizational expectations (Mathis and Jackson, 2010). Human resources have a strategic role in a company because they are the main driver in an activity process and determine the smooth running of activities (Qustolani, 2017). There was 2 female personnel in charge of the Aedes aegypti mosquito control program in the working area of Juanda Airport. They were aged 46 years and 28 years in the Environmental Risk Control Division. One of them had attended a Training of Trainer (TOT), supporting her expertise and skills in carrying out Aedes aegypti mosquitoe control measures. They were highly educated as one had a bachelor's degree and the other had associate degree of environmental health.

The personnel at the health office was responsible for supervising and preparing reports of larva survey, larva identification, larva eradication, and fogging. Besides, they also provided counselling and guidance to larvamonitoring cadres and residents of Semampir village, thereby making the program run smoothly. The number of personnel was also adequate and in accordance with the standard which requires personnel to have appropriate educational competencies, for example, being a sanitarian or entomologist (Indonesian Ministry of Health, 2007).

The control measures for Aedes aegypti mosquitoes ranged from larva survey, larva identification, larvasidation, and fogging. The personnel was assisted by the larva-monitoring cadres who had received training from Class 1 Surabaya Port Health Office. The cadres consisted of 5 women aged 30-40 years and graduating from junior high school (1 person) and senior high school (4 people). One's education level is closely related to the broadness of knowledge, understanding, and problem solving (Muliawati, 2016).

Besides, there was a relationship between the cadre's education levels and their performance in eradicating dengue 
(Indarwati and Prayitno, 2016). All cadres in Semampir had attended training (100\%). Two people took training from the primary healthcare center and the Class 1 Surabaya Port Health Office, and three people received training from the Class 1 Surabaya Port Health Office. The cadres actively carried out larva surveys in 4 days at the fastest and one week at the longest.

In addition to examining Aedes aegypti mosquito larva, the cadres also provided counselling on how to prevent mosquito larva to the residents. Their roles will be under supervision and guidance from the Class 1 Surabaya Port Health Office. The cadres received facilities such as flashlights, stationery, larvicide powder, larva survey forms and uniforms from the Class 1 Surabaya Port Health Office. The incentives given was Rp. $150,000.00$ per month per person. The personnel aspect in the Aedes aegypti mosquito control measures accorded with the SOP.

\section{Budget (Money)}

Budget is a written plan on organization's activities stated in units of money or in units of services or goods (Nafarin, 2013). It is an influential instrument on implementing programs (Fitriyah and Fauzy, 2017). The budget for the Aedes aegypti control program was allocated from the 2019 Budget Implementation List (DIPA). There were four activities that required budgets, such as larva survey, larva eradication, fogging, and socialization.

\section{Method}

A method is a rule implemented to execute real plans and achieve goals optimally (Sanjaya, 2010). There were four methods used in the Aedes aegypti control program.

\section{Larva Survey}

Monthly larva surveys were conducted visually by looking for larva in each water reservoir, both outside and inside the house. The Class 1 Surabaya Port Health Office also took larva samples from some water reservoirs. According to the SOP, the larva survey indicators include the House Index (HI), Container Index (CI), and Breteau Index (BI). The HI was measured by dividing the number of positive-larva houses by the number of inspected houses. The CI was calculated by dividing the number of positive-larva containers by the number of inspected containers. While, the BI was measured by dividing the number of inspected containers by a hundred inspected houses.

The larva survey was carried out by mapping survey locations, and the examination was then done by checking all water reservoirs which possibly become the mosquito breeding sites. Prasetyowati et al. (2014) stated that an Aedes aegypti mosquito is anthropophilic or usually bites humans during a few hours of the dawn and before dusk. Inspection of mosquito larva was carried out to large water reservoirs (drums, jars, and bathtubs) and small water reservoirs (flower vases and pots filled with cloudy water), the inspection was done by moving the water to other buckets or scoops. The larva in dark places and cloudy waters were checked using a flashlight.

The results are in line with research by Nadifah et al. (2016) stating that Aedes aegypti larva were found in many containers inside the house. This was due to the habit of collecting water for daily use in an open-air house, thus attracting adult mosquitoes to lay eggs.

The SOP stated that the larva survey should use a single larva method. This method is performed by checking water reservoirs, taking 1 larva from each container using a pipette, putting it in a petri dish, and storing it in a bottle labelled by location.

\section{Identification of Mosquito Larva}

Mosquito larva was identified after water reservoir survey and sampling. Mosquito larva was identified using a 
microscope in an entomology laboratory. First, the chloroform was put onto cotton and then onto a petri dish containing mosquito larva. The dead mosquito larva was then taken slowly with a needle, put on a preparatory slide, and covered with a slide cover. Their characteristics were identified as written in the larva identification guidebook.

According to Sianipar et al. (2018), Aedes aegypti mosquito larva has a pair of siphon hairs, a short and fat siphon, comb scales without lateral spines, and an open saddle on the anal segment. The method of mosquito larva identification complied with the SOP.

\section{Larva eradication}

Larva eradication was carried out at the same time as the larva survey. It was done by putting larvicide powder packaged in 10-gram plastic bags with small holes and dropped into a water reservoir. The larvicide powder would stick to the walls of the water reservoir for up to 3 months. The volume of larvicide given must be appropriate. According to research conducted by Fuadzy et al. (2015), the resistance ratio analysis, which was obtained by comparing each LC50 and LC99 larva with the standard larva, indicated that in general Ae larva. aegypti began to be resistant to Temephos (RR>1). Then, the larva-monitoring cadres distributed the larvicide powder to residents who were taught about how to use it.

\section{Fumigation}

Fumigation was carried out in a total area of 20 hectares each year or estimated at 5 hectares each month. Adult Aedes aegypti mosquitoes were controled by fumigation. According to Syamsir and Daramusseng (2018), fumigation requires spatial-based mapping of the dengue fever to identify susceptible areas. Fumigation was carried out in the afternoon or morning where the wind was calm. Such a condition is the perfect time for the Aedes aegypti mosquitos breeding. Fumigation was carried out using the Swingfog SN 50 which uses gasoline for the fog engine and diesel fuel as an insecticide mixture (Lamda Cyhalotrin). How to work using a pulsed burst pattern. When the fuel mixed with air, it resulted in the combustion chamber vibrating at 90 pulses per second. The gas produced from the chamber would then exit through a small pipe. The chemical solution used would be placed at the end of the resonator and go through the gas pulse. After that, the chemical would be scattered into smaller pieces which were immediately blown into the air through as a thick fog. Inside, the machine was set at about $40-60^{\circ} \mathrm{C}$.

All parts outside the house, such as the yard, were targetted as the Aedes aegypti mosquitoes flied from outside into the building. The fumigation works through a knock down effect, in which after the mosquito encounters the insecticide droplets, it is likely to die in 24 hours (Indonesian Ministry of Health, 2012). According to the Class 1 Surabaya Port Health Office, fumigation for yards and houses in urban areas usually requires 3-5 minutes of time per house. In oneworking day, one worker can fog 20-25 houses on average; however, this is influenced by conditions such as settlement density and location (Rahmadi, 2017). The fumigation complied with the SOP.

\section{Tools}

The equipment used to conduct larva survey, larva identification, and fogging was explained in this section.

\section{Larva Survey}

The equipment included a larva inspection form, stationery, and a larva survey kit such as a scoop, a flashlight, and a small bottle. The larva inspection form and stationery were used to record the number of visited houses and the survey locations. The scoop was used to take 
water samples in a reservoir which may contain mosquito larva. A flashlight was used as lighting aids in identifying larva in a dark water reservoir. The small bottle was used to store mosquito larva taken from a water reservoir for further laboratory examination. Overall, the equipment was already in accordance with the SOP.

\section{Mosquito Larva Identification}

The equipment used in the identification of mosquito larva was petri dishes, needles, preparatory slide, slide cover, and a microscope. The mosquito larva was put onto a petridish and was then given a chloroform. The needle was used to carefully collect chloroformed mosquito larva body and keep it intact and easy to identify. Slide cover was used to keep the specimen, i.e., the larva, in the desired position for easy identification, while the microscope could produce a closer look at small larva and identify their characteristics and types. The equipment used in the mosquito larva identification was suitable with the SOP.

\section{Larva eradication}

The equipment used in larva eradication included a larvasidation form and stationery to record the amount of given larvicide and the number of residents who received bags of larvicide powder. The Class 1 Surabaya Port Health Office used the standardized instrument during this process.

\section{Fumigation}

Fumigation was done using a jerry can, fumigation machine, and a fumigation report form. The jerry can functions as a mixing place for the insecticide (Lamda Cyhalotrin) and diesel fuel as well as a container for gasoline. The fumigation machine was used to spray the insecticide. The Swingfog SN 50 was chosen since it was effective for indoor use. Meanwhile, the fumigation result form was used to record the control measures such as the number of used materials, location, and the number of house fumigation. The equipment used for fumigation complied with the SOP.

\section{Materials \\ Larva eradication}

Materials used in larva eradication were larvicide powder that contains Temephos. Larvicide powder was put into a water reservoir to kill Aedes aegypti mosquito larva. The materials should be suitable with the needs for the procurement of material expenditures allocated from the 2019 Budget Implementation List.

Based on research conducted by Basri and Hamzah (2017), larvicide powder at $1 \%$ Temephos with a concentration of $300 \mathrm{mg} / \mathrm{L}$ can kill the entire sample of Aedes aegypti larva at the 4th hour (240th minute). It is more effective than the natural larvicide (Bacillus thuringiensis israelensis). The materials used for Aedes aegypti mosquito control accorded with the SOP.

\section{Fumigation}

Materials used in fumigation were Lamda Cyhalotrin, diesel dex, and gasoline. Twenty-five grams per liter of Lamda Cyhalotrin which belongs to the pyrethroid group were used as vector repellent for Aedes aegypti mosquitoes. The susceptibility test showed that adult Aedes aegypti mosquitoes were bred to the 3rd generation using insecticide with $0.05 \%$ of Lamda Cyhalotrin as the active ingredient, and they were categorized as resistant to the insecticide (Putra et al., 2016).

Solar dex was used as a mixture medium for Lamda Cyhalothrin, and gasoline was used as fuel for the fog machines. The materials used in fumigation complied with the SOP.

\section{Socialization (Market)}

Socialization through lecture and kind of media may increase one's 
knowledge (Mayasari and Wahyono, 2016). It aims to make the community understand the situation and benefits of the Aedes aegypti mosquito vector control in everyday life.

The socialization of the Aedes aegypti mosquito control had been practiced according to the SOP.

\section{Technology}

The technological equipment used to support the Aedes aegypti mosquito control included a laptop or computer, printer, microscope, fumigation machine, Microsoft office software, Health Quarantine Information System (SINKARKES), and email. A laptop or computer was used to process data and to compile reports, and the printer was used to print the reports. Some tech-based equipment used were fumigation machines and microscopes. The Class 1 Surabaya Port Health Office had 3 microscopes to identify types of larva and 6 fumigation machines to eradicate adult Aedes aegypti mosquitoes. A soft trap technology was also used in processing data. Microsoft office software was required to recap and then process data, and the reports were disseminated via email and the Health Quarantine Information System website.

\section{Information}

Technology advancement places information as a very important resource that needs to be managed properly (Amri, 2016). Aa good reporting system is necessary to present information accurately and realistically. The SOP stated that the reports of Aedes aegypti mosquito control measures should be written in forms of SINKARKES reports, annual reports, monthly reports, and Surabaya Port Health Office profiles. Further, information exchange is required to control and prevent dengue outbreaks. Reports are presented in narratives, study results, dengue vector entolomological surveys, details on action plans for control or management, new development in insecticide and spray equipment, and other related information (WHO, 2012).

\section{CONCLUSION}

The personnel from the Class 1 Surabaya Port Health Office and the larvamonitoring cadres had implemented managerial components such as man, budget, tools and materials, technology (machine), socialization (market), and information according to the SOP. Meanwhile, the method was not following the standard. The researchers recommended carrying out one larva from each container during the larva survey.

\section{REFERENCES}

Amri. 2016. Analisis Pemanfaatan Teknologi Informasi dan Komunikasi dalam Menunjang Terwujudnya Makassar Sebagai "Smart City". Jurnal Komunikasi KAREBA, 5(2): 431-445. http://dx.doi.org/10.31947/kjik.v5i2 .1916.

Atikasari, S; Sulistyorini, L. 2018. Pengendalian Vektor Nyamuk Aedes aegypti di Rumah Sakit Kota Surabaya. The Indonesian Journal of Public Health, 13(1): 71-82. http://dx.doi.org/10.20473/ijph.v13i 1.2018.73-84.

Basri, S dan Hamzah, E. 2017. Penggunaan Abate dan Bacillus Thuringensis var. Israelis Di Kantor Kesehatan Pelabuhan Kelas II Samarinda Wilayah Kerja Sanggata Terhadap Kematian Larva Aedes sp. AlSihah: Public Health Science Journal, $\quad 9(1)$ : 85-93. https://doi.org/10.24252/as.v9i1.31 98

Centers for Disease Control and Prevention. 2010. Epidemiology Dengue Homepage.

Fitriyah, S; Fauzy, MQ. 2017. Politik Anggaran Pemerintah Daerah 
Perspektif Maqasid Syari'ah: Studi Analisis Sektoral pada APBD Kabupaten Bangkalan Tahun 20132015. Jurnal Ekonomi Syari'ah Teori dan Terapan, 4(10): 787-801. http://dx.doi.org/10.20473/vol4iss2 $01710 \mathrm{pp} 787$.

Fuadzy, H; Hodijah, DN; Jajang, A; Widawati, M. 2015. Kerentanan Larva Aedes aegypti Terhadap Temepos di Tiga Kelurahan Endemis Demam Berdarah Dengue Kota Sukabumi. Buletin Penelitian Kesehatan, 43(1): 41-46. DOI : 10.22435/bpk.v43i1.3967.41-46.

Indarwati; Prayitno, H. 2016. Analisa Faktor Kinerja Kader Jumantik Dalam Pemberantasan DBD di Kelurahan Kadipiro Kota Surakarta. Indonesian Journal on Medical Science, 3(2): 100-108.

Istiqomah, M; Syahrul, F. 2016. Faktor Risiko Aktivitas, Mobilitas dan Menggantung Pakaian terhadap Kejadian Demam Berdarah pada Anak. Jurnal Keperawatan Muhammadiyah, 1(2): 1-9.

Indonesian Ministry of Health. 2007. Pedoman Teknis Pengendalian Resiko Kesehatan Lingkungan di Pelabuhan/Bandara/Pos Lintas Batas dalam Rangka Karantina Kesehatan. Jakarta: Indonesian Ministry of Health.

Indonesian Ministry of Health I. 2010. Demam Berdarah Dengue. Jakarta: Buletin Epidemiologi.

Indonesian Ministry of Health. 2012. Pedoman Penggunaan Insektisida (Pestisida) dalam Pengendalian Vektor. Jakarta: Indonesian Ministry of Health.

Indonesian Ministry of Health. 2016. Pusat Data dan Informasi Kementerian Kesehatan RI: Situasi DBD di Indonesia. Jakarta: Indonesian Ministry of Health.

Manullang. 2008. Dasar-Dasar Manajemen. Yogyakarta: Ghalia Indonesia.
Mathis and Jackson. 2010. Human Resource Management. 13th Edition. Ohio: South-Western College Publishing.

Mayasari, ML; Wahyono, B. 2016. Efektivitas Penyuluhan Kesehatan dengan Metode Ceramah Disertai Pemanfaatan Medi Booklet dalam Upaya Meningkatkan Pengetahuan Ibu tentang Penyakit Pneumonia pada Balita di Kelurahan Bandarharjo Kecamatan Semarang Utara Kota Semarang Tahun 2014. Unnes Journal of Public Health, 5(1): https://doi.org/10.15294/ujph.v5i1. 9701.

Mufidz. 2016. Evaluasi Input Sistem Surveilans Demam Berdarah Dengue di Dinas Kesehatan Kab. Tegal. Unnes Journal of Public Health, 5(2): 156-166.

Muliawati, E. 2016. Hubungan Pendidikan dan Pengetahuan Jumantik dengan Keberhasilan Program PSN di Kelurahan Tanah Kalikedinding Kota Surabaya. Jurnal Keperawatan Muhammadiyah, 1(2): 1-16.

Nadifah, F; Muhajir, NF; Arisandi, D; Lobo MDO. 2016. Identifikasi Larva Nyamuk pada Tempat Penampungan Air di Padukuhan Dero Condong Catur Kabupaten Sleman. Jurnal Kesehatan Masyarakat Andalas, 10(2): 172178.

https://doi.org/10.24893/jkma.10.2. 172-178.2016.

Nafarin. 2013. Penganggaran Perusahaan Edisi ketiga, Cetakan kedua. Jakarta: Salemba Empat.

Nani. 2017. The Relationship Between PSN Behavior with Existence Larvae of Aedes aegypti in Port of Pulang Pisau. Jurnal Berkala Epidemiologi, $\quad 5(1): .1-12$. http://dx.doi.org/10.20473/jbe.V5I1 2017.1-12.

Prasetyowati, H; Marina, R; Hodijah, DN; 
Widawati, M; Wahono, T. 2014. Survei Jentik dan Aktivitas Nokturnal Aedes spp. di Pasar Wisata Pangandaran. Jurnal Ekologi Kesehatan, 13(1): 33-42.

Putra, YNE; Koerniasari; Mamik. 2016. Uji Kerentanan Nyamuk Aedes aegypti Terhadap Lamda Sihalotrin dan Sipermetrin Tahun 2016. Gema Kesehatan Lingkungan, 14(3): 156161.

Qustolani, A. 2017. Pengaruh Kepuasan Kerja, Keadilan Prosedural dan Kompensasi Terhadap Kinerja Karyawan. Jurnal Ilmiah Manajemen \& Akuntansi, 4(2): 7886.

Rahmadi, R. 2017. Input Factor Analysis of Aedes aegypti Controlling in Port Health Office Class II Semarang Territory. Jurnal Kesehatan Lingkungan, 9(1): 1120.

http://dx.doi.org/10.20473/jkl.v9i1. 2017.11-20

Sanjaya, W. 2010. Strategi Pembelajaran
Berorientasi Standar Proses

Pendidikan. Jakarta: Prenada Media Group.

Sianipar, MY; Anwar, C; Handayani, D. 2018. Identifikasi Larva Nyamuk di Tempat Penampungan Air Serta Pengetahuan, Sikap dan Tindakan Petugas Kebersihan tentang Perkembangbiakan Nyamuk di Taman Wisata Sejarah Bukit Siguntang Palembang. Jurnal Kedokteran Kesehatan, 5(2): 78-88. https://doi.org/10.32539/JKK.v5i2. 6129.

Syamsir; Daramusseng, A. 2018. Analisis Spasial Efektivitas Fogging di Wilayah Kerja Puskesmas Makroman, Kota Samarinda. Jurnal Nasional Ilmu Kesehatan, 1(2): 1-7.

WHO. 2012. Demam Berdarah Dengue: Diagnosis, Pengobatan, Pencegahan dan Pengendalian. Jakarta: EGC.

WHO. 2014. Dengue and Severe Dengue. World Health Organization. 